\title{
The Influence of Effort of Use, Features of Products and Promotions on Purchase Decisions and Customers Loyalty
}

\author{
Rahjuno Saktio Darpito \\ Narotama University, Indonesia \\ rahjunosd@gmail.com
}

\begin{abstract}
Absract. This study aims to analyze the influence of ease of use, product features, promotions and purchasing decisions in relation to the loyalty of T-Cash customers in Surabaya. The research method used is to use an explanatory type of research. With the number of samples, namely the T-Cash users who have not yet been approved, so it is necessary to do the calculation using the lemeshow formula. In the analysis of this study using data collection with the help of filling out questionnaires accompanied by Partial Least Square (PLS) analysis techniques. Research shows the ease of use variables, product features and promotions have a positive and significant relationship simultaneously and partially in its development.
\end{abstract}

Keyword:Ease of Use, Product Features, Promotions, Purchasing Decisions, Customer Loyalty.

\section{INTRODUCTION}

In its development the company is required to create a new innovation in order to bind loyal customers in the use of the products it markets.Tjiptono (2000: 110) defines consumer loyalty as a customer's commitment to a brand, product or supplier based on a very positive nature in long-term purchases. Loyalty is the formation of attitudes and patterns of behavior of a consumer towards the purchase and use of products as a result of their previous experience (Griffin, 2005: 75). Then it can be concluded that loyalty is formed from two components, loyalty as a behavior that is consistent repurchase and loyalty as an attitude that is a positive attitude towards a product or producer (service provider) coupled with a consistent purchase pattern.

Based on the above matrix, the researcher took the title "The Effect of Ease of Use, Product Features and Promotion of T-Cash Customer Purchasing and Loyalty Decisions in Surabaya.Can not be denied to create customers who are loyal to the company must have a different strategy than others based on certain factors such as ease of use, product features, promotions and purchasing decisions that will be made by prospective customers of the company's loyalty.

\section{LITERATURE REVIEW}

Ease of Use (X1)

The ease in using a product becomes the main factor in the customer's decision to make a purchase and become loyal in its use. This is of course based on the efficiency and effectiveness of a product in helping customers to support their daily needs. Davis in Nasution (2004: 5) defines ease of use (ease of use) as a level where one believes that a computer can be easily understood. Based on the definition above it can be concluded that ease of use will reduce the effort (both time and energy) of someone in learning something.

This research re-examines the role of ease of use on purchasing decisions and customer loyalty with the following indicators: Time Efficiency, Ability to Transact, Operational Ease (Amijaya: 2010).

Hypothesis 1: Ease of Use Significantly Influences the Purchase Decision.

Hypothesis 2: Ease of Use Significantly Influences Customer Loyalty.

\section{Product Features (X2)}

Features also help encourage customers in purchasing decisions and are loyal to the use of a product. In the opinion of Karen, et all (2013) states that features are attributes of a product that are used to meet the 
level of satisfaction of customer needs and desires, through having products, usage and product utilization. The more quality and sophisticated features that will be offered by the company, it can be ascertained that more and more customers are interested in using, buying and being loyal in using it for a long period of time.

This research examines the role of product features on purchasing decisions and customer loyalty with the following indicators: Diversity of Features, Quality of Features, Features of Features, Completeness of Features (Kotler and Keller: 2012).

Hypothesis 1: Product Features Significantly Influence Purchasing Decisions.

Hypothesis 2: Product Features Significant Influence on Customer Loyalty.

\section{Promotion (X3)}

Promotion is also a very important indicator in making customers decide to make a purchase and when they have felt the quality and benefits of the products offered by customers, they will indirectly become loyal in the use of products offered by the company. According to Tjiptono (2008: 79) suggests that promotion is one of the determinants of the success of a marketing program to provide information about the existence of a product.

This research examines the role of promotion in purchasing decisions and customer loyalty with the following indicators: Sales Promotion, Advertising, Sales Force, Public Relations / Public Relations, Direct Marketing (Kotler: 2009).

Hypothesis 1: Promotion Has Significant Effects on Purchase Decisions.

Hypothesis 2: Promotion Significantly Influences Customer Loyalty.

\section{Purchasing Decision (Y1)}

According to Philip Kotler and Gary Armstrong (2010: 202) who converted languages by Benjamin Molan, "Characteristics of buyers and their decision-making processes will lead to purchasing decisions". The buying decision itself according to Helga Drumond (2003: 68), is identifying all possible choices to solve the problem and assessing choices systematically and objectively and the objectives that determine their respective advantages and disadvantages.

This research re-examined the role of Purchasing Decisions on customer loyalty with the following indicators: Choice of products, Choice of time, Choice of places, Choice of number, Choice of payment methods (Kotler: 2000)

Hypothesis 1: Purchasing Decisions Are Significant About Customer Loyalty.

\section{METHODOLOGY}

In this study the author uses an explanatory research type. According to Singarimbun and Effendi (2008) explanatory research is a study that explains the causal relationship between variables through testing hypotheses. With the location of the research in Grahapari Surabaya Center which is located at Jln. Pemuda No 27 31, Surabaya. And the variables used as research are ease of use, product features, promotions, purchasing decisions and customer loyalty variables. In this study the number of customers using T-Cash is not known with certainty so that to calculate the minimum number of samples needed for research the author uses the Lemeshow formula for populations that are not known. Whereas for data collection techniques using questionnaires assisted with analysis methods using Partial Least Square (PLS) that uses SmartPLS3 software. 


\section{RESEARCH FRAMEWORK}

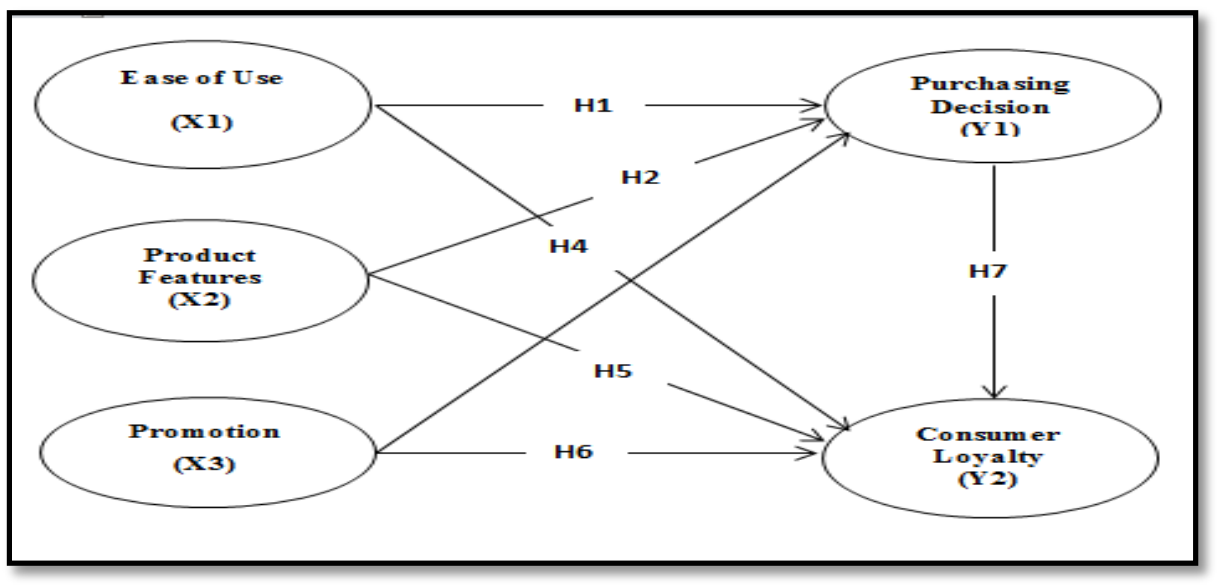

Figure 1: Framework for research concepts

Source: Data processed by the author

\section{Hypothesis:}

H1: Ease of Use Has a Positive and Significant Effect on Purchase Decisions.

H2: Product Features Have a Positive and Significant Effect on Purchasing Decisions.

H3: Product Features Have a Positive and Significant Effect on Purchasing Decisions.

H4: Ease of Use Has Positive and Significant Effects on Customer Loyalty.

H5: Product Features Have a Positive and Significant Effect on Customer Loyalty.

H6: Promotion Has Positive and Significant Effects on Customer Loyalty.

H7: Purchasing Decisions Have a Positive and Significant Effect on Customer Loyalty.

\section{RESULT AND DISCUSSION}

R-Square purchasing decision variable is 0.898 or $89.8 \%$. This result reflects that the independent variables of ease of use, product features and promotion contribute $89.8 \%$ to purchasing decisions and the remaining $10.2 \%$ are caused by other factors, while for variables R-Square customer loyalty has a value of 0.885 or $88.5 \%$. These results indicate that the ease of use, product features and promotions affect customer loyalty by $88.5 \%$ and the remaining $11.5 \%$ is influenced by other factors.

In testing the hypothesis a data must meet a criterion to say that the hypothesis is accepted if $\mathrm{t}$ statistics $>\mathrm{t}$ table and if $\mathrm{P}-\mathrm{V}$ aue $<0.05$ and the following results of the smartpls output of this study:

Tabel 1 : Path Coefficient

\begin{tabular}{|c|c|c|c|c|c|}
\hline Path Coefficient & $\begin{array}{l}\text { Sampel Asli } \\
\text { (O) }\end{array}$ & $\begin{array}{l}\text { Rata - Rata } \\
\text { Sampel (M) }\end{array}$ & $\begin{array}{l}\text { Standar } \\
\text { Deviasi } \\
\text { (STDEV) }\end{array}$ & $\begin{array}{l}\text { T Statistic } \\
(\mid \mathbf{O}, \text { STDEV } \mid)\end{array}$ & P Value \\
\hline $\begin{array}{l}\text { Ease Of Use (X1) } \rightarrow \text { Buying } \\
\text { Decision (Y1) }\end{array}$ & 0,212 & 0,211 & 0,043 & 4,981 & 0,000 \\
\hline $\begin{array}{l}\text { Ease Of Use (X1) } \rightarrow \text { Customer } \\
\text { Loyalty }\left(\mathrm{Y}_{2}\right)\end{array}$ & 0,100 & 0,097 & 0,047 & 2,111 & 0,035 \\
\hline $\begin{array}{l}\text { Product Features }(X 2) \rightarrow \text { Buying } \\
\text { Decision }(Y 1)\end{array}$ & 0,216 & 0,211 & 0,055 & 3,938 & 0,000 \\
\hline $\begin{array}{l}\text { Product Features } \quad(\mathrm{X} 2) \\
\text { Customer Loyalty }(\mathrm{Y} 2)\end{array}$ & 0,153 & 0,152 & 0,072 & 2,113 & 0,035 \\
\hline $\begin{array}{l}\text { Promotion (X3) } \rightarrow \text { Buying } \\
\text { Decision }(Y 1)\end{array}$ & 0,692 & 0,635 & 0,050 & 12,453 & 0,000 \\
\hline $\begin{array}{l}\text { Promotion }(X) \rightarrow \text { Customer } \\
\text { Loyalty }(\mathrm{Y} 2)\end{array}$ & $-0,181$ & $-0,192$ & 0,088 & 2,058 & 0,040 \\
\hline $\begin{array}{l}\text { Buying Decision } \text { (Y1) } \vec{\rightarrow} \\
\text { Loyalitas Pelan Customer Loyalty } \\
\text { (Y2) }\end{array}$ & 0,898 & 0,912 & 0,110 & 8,165 & 0,000 \\
\hline
\end{tabular}

\section{Direct Influence}




\section{Hipotesis 1 : Ease of Use and Its Impact on Purchasing Decisions}

The easier the product is used by all ages and society, the more likely it is in consumer purchasing decisions in their use of daily needs, while making consumers not hesitate to be loyal to the product. The ease of use in this study is closely related to how to use it. the T-Cash product itself covers all ages of consumers who will use it. In the ease of use this will make it easier for PT. Telkomsel in capturing a broad market share going forward. Ease of use influences consumer purchasing decisions going forward (Suharti: 2012).

The results of the study show that the ease of use has a positive and significant effect on purchasing decisions this is in accordance with previous research from Denni Ardyanto, Heru Susilo, Riyadi Journal of Business Administration (JAB) Vol. 22 No. May 1, 2015 with the title "Effect of product quality, Effect of Ease and Trust Using E-Commerce on Online Purchasing Decisions (Survey on Consumers www.petersaysdenim.com).

H1: Ease of Use Has a Positive and Significant Effect on Purchase Decisions.

\section{Hipotesis 2 : Product Features and Their Effects on Purchasing Decisions}

The more complete features available on a product, the more likely the customer will decide to buy the product. Conversely, the more incomplete features that exist on a product, the smaller the chance the customer decides to purchase the product. The influence of product features on purchasing decisions has been proven in research conducted by Karen, et all. (2013) who found the perception effect of product features had a positive effect on purchasing decisions.

The results of the study show that product features have a positive and significant effect on purchasing decisions, this is supported by the previous research from Linggar Eka Setyanto, Zainul Arifin, Sunarti Journal of Business Administration (JAB) | Vol. 46 No. May 2, 2017 with his research entitled "The Influence of Product Attributes on Purchasing Decisions" (Survey of Apple iPhone Buyers of Undergraduate / College Students of the Faculty of Administrative Sciences 2013/2014 Business Administration Study Program Universitas Brawijaya Malang).

H2: Product Features Have a Positive and Significant Effect on Purchasing Decisions.

\section{Hipotesis 3 : Promotion and Its Impact on Purchasing Decisions}

According to Tjiptono (2008: 79) suggests that promotion is one determinant of success in a marketing program to provide information about the existence of a product. In this opinion, it can be concluded that an attractive and continuous promotion will provide an understanding of the products offered by the company, of course, with consumers on a broader range, so that it will indirectly be able to help consumers in considering the product. to help support the needs needed

The results of this study also show that product features have a positive and significant effect on purchasing decisions in accordance with previous journals made by the results of this study in accordance with previous research that was taken from Tulandi Riry Anggia, Lotje Kawet, Imelda Ogi Journal of EMBA 1047 Vol.3 No.2 June 2015, pg. 1041-1050 ISSN 2303-1174 with his research entitled "Analysis of the Effect of Promotion Strategy, Price, and Satisfaction on Consumer Loyalty of the Manado Post Newspaper".

H3: Product Features Have a Positive and Significant Effect on Purchasing Decisions.

\section{Hipotesis 4 : Ease of Use and Its Effect on Customer Loyalty}

Theoretical definition according to Thomson with his book entitled "Introduction to Business" A company can also expand its products by making these products become more accessible and easier to use or buy. Because more and more consumers make decisions to buy products offered by the company. , then indirectly it will also help consumers enjoy the quality of the products they use. And when in the use of consumers feel satisfaction, then indirectly will help build consumer trust and make these customers loyal to use the product for a long time.

In this study shows that ease of use has a positive and significant influence on customer loyalty, this is supported by previous research conducted by Chien-Chung Tu, Fang a and Chwen-Yea Lin Quoting in the JOURNAL OF COMPUTERS, VOL. 7, NO. 3, MARCH 2012 and his research entitled "Perceived Ease of Use, Trust, And Satisfaction As Determinants Of Loyalty In E-Auction Marketplace"

H4: Ease of Use Has Positive and Significant Effects on Customer Loyalty. 


\section{Hipotesis 5 : Product Features and Their Effects on Customer Loyalty}

According to Boyd et all, in M Rhendria Dinawan, (2010), after consumers obtain information about a product, they will use that information to evaluate sources for features such as convenience, personnel and physical or features offered.

The more complete features available on a product, the more likely the consumer will decide to buy the product. Conversely, the more incomplete features that exist on a product, the smaller the chance the consumer decides to make a purchase for the product. The feature is a very important component of purchasing and loyalty decisions that will be built by the customer.

By definition operational can be seen with a single feature of T-Cash customers will get a lot of functions, because T-cash collaborates with many tenants who have big names in Indonesia, besides the quality offered is also able to compete with similar features so that T-Cash is feasible used.

The results showed that product features had a positive and significant effect on Customer Loyalty, this was supported by the previous research from Linggar Eka Setyanto, Zainul Arifin, Sunarti Journal of Business Administration (JAB) | Vol. 46 No. May 2, 2017 with his research entitled "The Influence of Product Attributes on Purchasing Decisions" (Survey of Apple iPhone Buyers of Undergraduate / College Students of the Faculty of Administrative Sciences 2013/2014 Business Administration Study Program Universitas Brawijaya Malang).

H5: Product Features Have a Positive and Significant Effect on Customer Loyalty.

\section{Hipotesis 6 : Promotion and Its Impact on Customer Loyalty}

According to Buchari Alma (2007: 79) promotion is a form of marketing communication which is a marketing activity that seeks to disseminate information, influence, and remind the target market of the company and its products to be willing to accept, buy and be loyal to the products offered by the company concerned. A promotion that is carried out continuously will provide an understanding of the products offered by the company, of course, with consumers on a broader range, so that it will indirectly be able to help consumers in considering these products to help support the needs they need.

By definition, operational promotions that have been carried out by PT. Telkomsel as a company that develops the T-Cash feature can be said to be very large. Apart from promoting on advertising and social media media, PT. Telkomsel also started developing T-Cash by making promotions and collaborating with more than 100 tenants with big names in Indonesia.

In this study shows that promotion has a positive and significant effect on customer loyalty, this is supported by previous research conducted by Tulandi Riry Anggia, Lotje Kawet, Imelda Ogi in the EMBA Journal 1047 Vol.3 No.2 June 2015, p. 1041-1050 ISSN 2303-1174 with his research entitled "Analysis of the Effect of Promotion Strategy, Price, and Satisfaction on Consumer Loyalty of the Manado Post Newspaper"

H6: Promotion Has Positive and Significant Effects on Customer Loyalty.

\section{Hipotesis 7 : Purchasing Decisions and Their Effects on Customer Loyalty}

Philip Kotler describes a model of the stages in the buying process carried out by consumers based on the sequence of stages of a particular buying process. In carrying out the purchasing process, consumers pass through five stages, namely: problem recognition, information search, evaluation, purchasing decisions, and post-purchase behavior.

Due to the variety of functions and uses of cash plus good quality and attractive promos, many customers want to try and use cash to enjoy the benefits offered to help support their daily needs to be more effective, efficient and flexible. From the beginning of its development, T-Cash products have customers that continue to increase.

In this study shows that ease of use has a positive and significant influence on customer loyalty, this is supported by previous research conducted by Chien-Chung Tu, Fang a and Chwen-Yea Lin Kwoting with JOURNAL OF COMPUTERS, VOL. 7, NO. 3, MARCH 2012 and his research entitled "Perceived Ease of Use, Trust, And Satisfaction As Determinants Of Loyalty In E-Auction Marketplace"

H7: Purchasing Decisions Have a Positive and Significant Effect on Customer Loyalty

\section{Indirect Influence}

1) Product Features (X2) Have An Effect On Customer Loyalty (Y2) Through Purchasing Decisions (Y1) Positively And Significantly. 
Product Features (X2) Have An Effect On Customer Loyalty (Y2) Through Purchasing Decisions (Y1) Positively And Significantly. This can be seen because the t-table value is 3.481>1.661 and the P-Value value is $0.000<0.05$.

2) Ease Of Use (X1) Has An Effect On Customer Loyalty (Y2) Through Purchasing Decisions (Y1) Positively And Significantly.

Ease Of Use (X1) Has An Effect On Customer Loyalty (Y2) Through Purchasing Decisions (Y1) Positively And Significantly. This can be seen because the t-table value is 3.876>1.661 and the PValue value is $0.000<0.05$.

3) Promotion (X3) has an effect on customer loyalty (Y2) through purchasing decisions (Y1) positively and significantly.

Promotion (X3) has an effect on customer loyalty (Y2) through purchasing decisions (Y1) positively and significantly. This can be seen because the t-table value is $6.307>1.661$ and the PValue value is $0.000<0.05$.

\section{CONCLUSION AND LIMITATION}

\section{Conclusion}

From the results of data processing above the ease of use, product features and promotions have a direct and significant influence on purchasing decisions and customer loyalty. This means that companies that have product features that are accompanied by the ease of use and promotions they offer will result in consumer purchasing decisions and opportunities to get loyal customers. As for the ease of use, product features and promotions and their influence on customer loyalty through purchasing decisions has a positive and significant indirect effect. This shows that the three variables can open opportunities for loyal customers to use the features offered through the increasing number of purchasing decisions from consumers

\section{Limitation}

The findings in this study still have limitations, which can also be used for further research. First, the sample used in this study is only a small sample with 1 location, namely grahapari, which is located at jln. Youth number 27-31 surabaya is expected to have further coverage in the next sample. The second is expected that further research can examine more factors other than the factors of this study so that more concrete data will be obtained in the future.

\section{REFERENCES}

[1] Atmaja, H.S. 2003. Pengaruh Kualitas Jasa Terhadap Kepuasan Pelanggan Dalam Membangun Loyalitas Pelanggan (Studi Kasus Pelanggan Multimedia Akses PT Telkom). Tesis FakultasEkonomi Universitas Indonesia, tidak diterbitkan.

[2] Chwen-Yea Lin Quoting et All : JOURNAL OF COMPUTERS, VOL. 7, NO. 3, MARCH 2012 and his research entitled "Perceived Ease of Use, Trust, And Satisfaction As Determinants Of Loyalty In E-Auction Marketplace"

[3] Davis in Nasution 2004, Keputusan Pembelian : Menciptakan Faktor Pendorong Keputusan Pembelian. Erlangga; Jakarta

[4] Griffin, Jill. 2005. Customer Loyalty: Menumbuhkan dan Mempertahankan Kesetiaan Pelanggan Edisi Revisi dan Terbaru. Diterjemahkan oleh Dr. Dwi Kartini Yahya. Erlangga; Jakarta.

[5] Imelda ogi et all, Analisis Pengaruh Strategi Promosi, Harga, Dan Kepuasan Terhadap Loyalitas Konsumen Surat Kabar Manado Post. Jurnal EMBA 1041Vol.3 No.2 Juni 2015, Hal. 1041-1050

[6] Kotler, Philip dan Gary Amstrong, 1996, Dasar-Dasar Pemasaran, Edisi V, jilid 2,Intermedia, Jakarta.

[7] Kotler dan Amstrong, 2001, Prinsip-prinsip pemasaran, Edisi keduabelas, Jilid 1,Jakarta: Erlangga.

[8] Riduwan \& Kuncoro Engkos Achmad. 2014. Cara Menggunakan Dan MemakaiAnalisisJalur (Path Analysis). Bandung: Alfabeta.

[9] Riya et All, Journal of Business Administration (JAB) Vol. 22 No. May 1, 2015 with the title "Effect of product quality, Effect of Ease and Trust Using E-Commerce on Online Purchasing Decisions (Survey on Consumers www.petersaysdenim.com).

[10] Sunarti et All, Journal of Business Administration (JAB)|Vol. 46 No. May 2, 2017 with his research entitled "The Influence of Product Attributes on Purchasing Decisions" (Survey of Apple iPhone Buyers of 
Undergraduate / College Students of the Faculty of Administrative Sciences 2013/2014 Business Administration Study Program Universitas Brawijaya Malang).

[11] Tjiptono, Fandy 2004, Strategi Pemasaran, Edisi 2, Penerbit Andi, Yogyakarta 